НАУКОВИЙ ВІСНИК

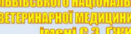

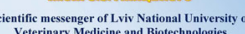

$18=0$

$\sqrt{3}$

$7=$

СЕРЯя: ВЕТЕРИНАРНН НАУКИ

Том 23 № 101

2021
Науковий вісник Дьвівського національного університету ветеринарної медицини та біотехнодогій імені С.3. Гжицького. Серія: Ветеринарні науки

\author{
Scientific Messenger of Lviv National University \\ of Veterinary Medicine and Biotechnologies. \\ Series: Veterinary sciences
}

UDC 636.2:616 - 002.228:619:617.5

\title{
Ungulomycosis of cattle: etiological factors and pathogenetic mechanisms
}

\author{
Y. G. Krupnyk, S. V. Tsisinska, Yu. M. Lenjo \\ Stepan Gzhytskyi National University of Veterinary Medicine and Biotechnologies Lviv, Ukraine
}

Article info

Received 22.01.2021

Received in revised form 24.02 .2021

Accepted 25.02.2021

Stepan Gzhytskyi National University of Veterinary Medicine and Biotechnologies Lviv, Pekarskaya Str., 50, Lviv, 79010, Ukraine

Tel.: +38-093-985-15-22

E-mail:yurijlenyo@gmail.com
Krupnyk, Y. G., Tsisinska, S. V., \& Lenjo, Yu. M. (2021). Ungulomycosis of cattle: etiological factors and pathogenetic mechanisms. Scientific Messenger of Lviv National University of Veterinary Medicine and Biotechnologies. Series: Veterinary sciences, 23(101), 100-106. doi: $10.32718 /$ nvlvet10117

Mycotic diseases, ie those caused by microscopic fungi, are widespread among animals. As for cattle, at present ungulomycosis has become the most widespread, in which keratolytic fungi affect the hooves of animals, causing complications such as deformities, pododermatitis, lesions of the hoof bone. Ungulomycosis (from the Latin ungula - hoof, Gr. Mykes - fungus) - a disease of the hooves, which are caused by microscopic fungi that have keratolytic properties. In most cases of ungulomycosis, its complications are most often registered, and not the disease itself, which does not allow to carry out effective preventive measures and treatment of animals in a timely manner. That is why the purpose of the work was to study and concretization the main factor of the disease and the contributing conditions for the disease. For this purpose the basic and additional clinical methods of research were used, including microscopy of the destroyed horn and sowing on nutrient media to determine the species content of microscopic fungi. The research was carried out in the farms of the western regions of Ukraine on cows of Black-Spotted and Holstein breeds in the stall period with tethered animals. It is found that the pathogenic action of microscopic fungi-keratomycetes on the hooves of cattle is carried out in the presence of favorable conditions of external and internal nature, primarily insufficient housing conditions and poor feeding. In particular, for osteodystrophy due to ungulomycosis, the destruction of the hoof's horn is accelerated, which complicates the pathological process. For purulent subdermatitis of traumatic origin, microscopic fungikeratomycetes act as an additional or contributing factor to the disease. Further research will focus on the development of effective treatments and measures to prevent ungulomycosis.

Key words: cattle, hoof horn, microscopic fungi-keratomycetes, ungulomycosis, osteodystrophy, hoof deformity, pododermatitis, hoof bone lesions (osteophytes, exostoses).

\section{Унгуломікоз великої рогатої худоби: етіологічні фактори та патогенетичні механізми}

\author{
Я. Г. Крупник, С. В. Цісінська, Ю. М. Леньо
}

Львівський національний університет ветеринарної медицини та біотехнологій імені С. 3. Гюицького, м. Львів, Україна

\footnotetext{
Мікотичні захворювання, тобто ті, які викликаються мікроскопічними грибами, мають широке поширення серед тварин. Щодо великої рогатої худоби, на даний час найбільшого поширення набув унгуломікоз, за якого кератолітичними грибами уражаються копитчя (ріг) тварин, спричинюючи такі ускладнення, як деформації, пододерматити, ураження копитцевої кістки. Унгуломікоз (від лат. ungula - копито, гр. mykes - гриб) - захворювання копитець, які спричинюються мікроскопічним грибами, ия мають кератолітичні властивості. Здебільшого за унгуломікозу найчастіше реєструються його ускладнення, а не саме захворювання, щзо не дозволяє своєчасно проводити ефективні профілактичні заходи та лікування тварин. Саме тому метою роботи було вивчення й конкретизація етіологічного фактора захворювання та сприяючих умов для виникнення хвороби. Для изього були використані основні й додаткові клінічні методи дослідження, включаючи мікроскопію зруйнованого рога та посіви на живильні середовища з метою ідентифікації видового складу мікроскопічних грибів. Дослідження проводились у господарствах західного регіону України
} 
на коровах чорно-рябої та голштинської породи у стійловий період за прив'язного утримання тварин. Встановлено, щчо хвороботворна дія мікроскопічних грибів-кератоміцетів на копития худоби здійснюється за наявності сприятливих умов зовнішнього та внутрішнього характеру, насамперед невідповідних умов утримання та неповноцінної годівлі. Зокрема, за остеодистрофії внаслідок унгуломікозу прискорюється руйнування копитцевого рогу, щзо ускладнює патологічний прочес. За гнійного пододерматиту травматичного походження мікроскопічні гриби-кератоміцети виступають у ролі додаткового фактору захворюваня. У подальшому дослідження будуть спрямовані на розробку ефективних методів лікування та заходів профілактики унгуломікозу.

Ключові слова: велика рогата худоба, копитиевий ріг, мікроскопічні гриби-кератоміџети, унгуломікоз, остеодистрофія, деформація копитецьь, пододерматит, ураження копитцевої кістки (остеофіти, екзостози).

\section{Вступ}

Мікотичні захворювання, тобто ті, які викликаються мікроскопічними грибами (від гр. mykes гриб), мають широке поширення як серед людей, так і тварин (Kisera et al., 2017). Водночас статистичні дані щодо їх поширення дещо занижені, оскільки значна частина населення не приділяе уваги цим захворюванням.

Щодо грибкових захворювань серед тварин, то реєструються вони здебільшого у клінічно вираженій формі, а такі, як унгуломікоз (від лат. ungula - копито) часто зараховуються до пододерматитів, або ж деформацій копитець. Підтвердженням цього $є$ дані (Izdepskyi et al., 2012) про те, що серед широкого поширення деформацій у корів (25-49\%) та коней (28\%), в $77 \%$ \% них етіологічним фактором визнавався мікозний.

У коней патологію білої лінії мікозного походження деякі фахівці називають оніхомікозом. Як відомо, так називається грибкове ураження нігтів у людей. На наш погляд, назва “унгуломікоз”, яку запропонували вчені Львівської ветеринарної школи (Malishevs'kij et al., 1991), більше конкретизує дану патологію не тільки у великої рогатої худоби, а й у коней.

\section{Матеріал і методи досліджень}

Дослідження проводили у господарствах західного регіону України на коровах чорно-рябої та голштинської породи у стійловий період за прив'язного утримання тварин.

Клінічні дослідження, які полягали у визначенні загального стану тварин і характеру місцевого процесу, проводили шляхом огляду та пальпації з використанням пробних щипців.

Діагноз ставили на основі клінічних ознак захворювання $з$ урахуванням анамнезу, аналізу годівлі, догляду й утримання тварин та брали до уваги динаміку біохімічних показників крові.

Підтверджували діагноз мікроскопією зруйнованого рогу та посівами на живильні середовища (агар Чапека, агар Сабуро) з метою встановлення видового складу мікроскопічних грибів.

\section{Результати та обговорення}

За унгуломікозу розпад рогу копитця переважно розпочинається 3 підошви. Спочатку 3'являються невеликі тріщини та плями темно-сірого кольору, в яких порушується структура рогової субстанції (рис. $1-4)$.

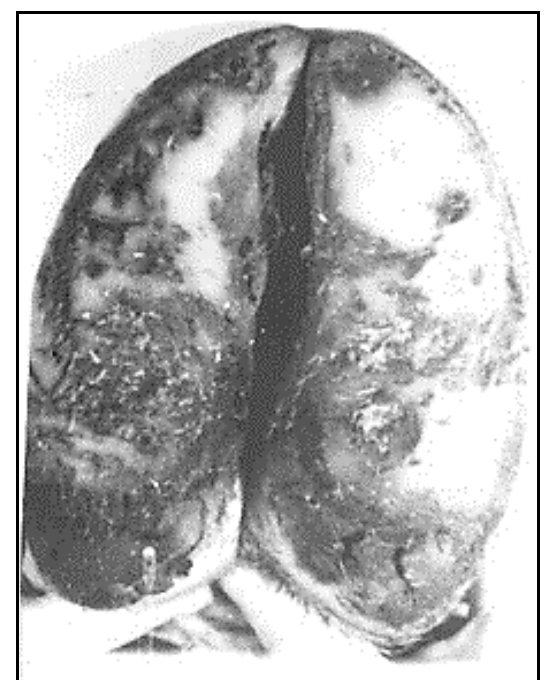

Рис. 1. Локальні й дифузні ураження підошви Копитець

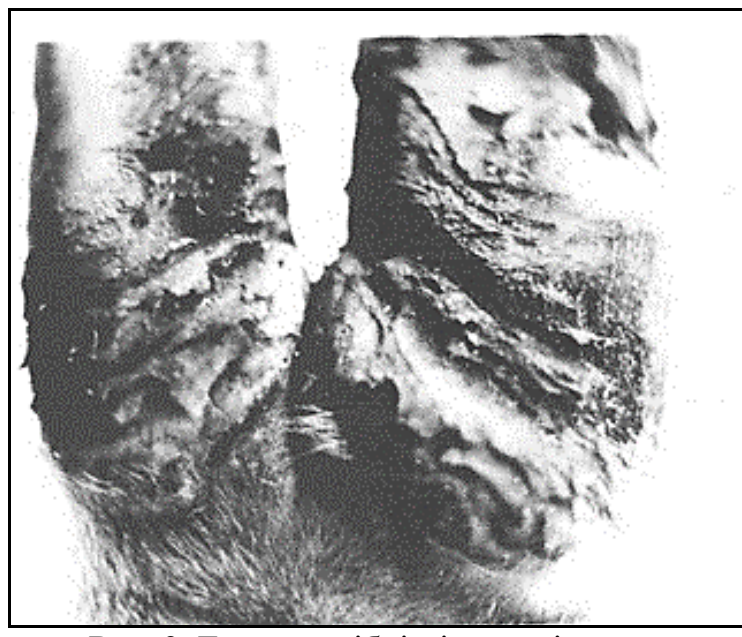

Рис. 2. Терасоподібні мікотичні ураження

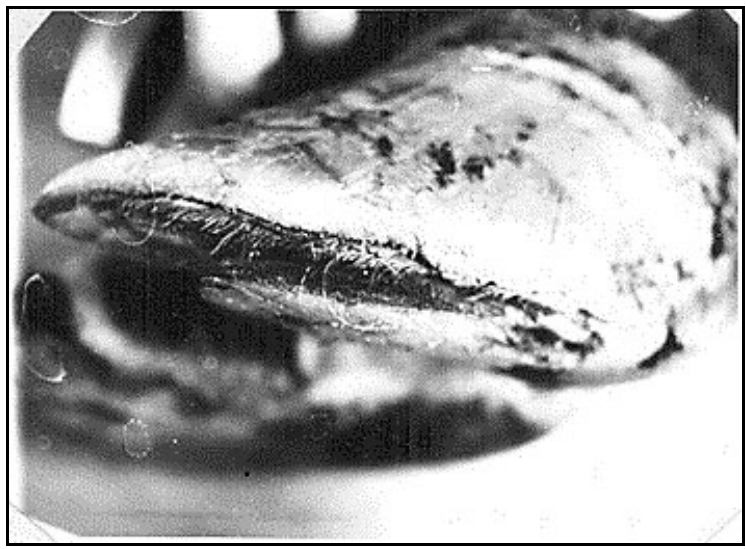

Рис. 3. Часткове відшарування підошви 
Надалі, за сприятливих умов, первинні вогнища поглиблюються й набувають округлої форми. В цих місцях рогова субстанція стає крихкою й легко відокремлюється.

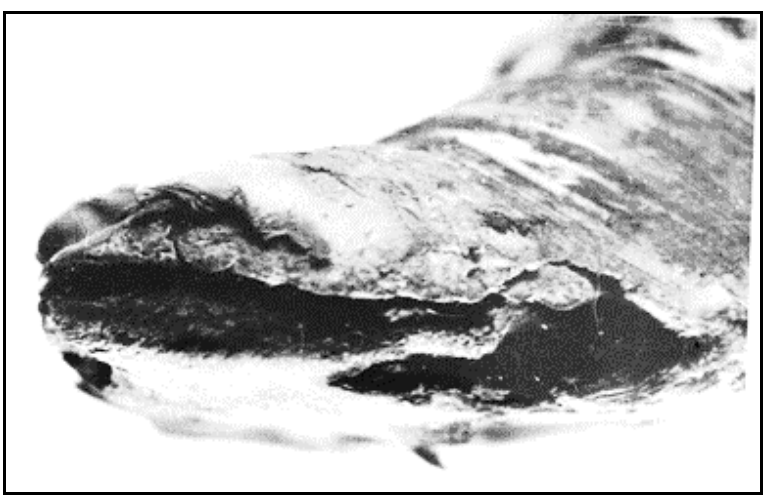

Рис. 4. Запущений випадок унгуломікозу

На місці зруйнованого рогу утворюються дефекти різної глибини (рис. 5). Характерним для такого процесу є розвиток терасоподібних заглиблень та своєрідного розшарування підошви по горизонталі. В підошві формуються норицеві ходи, які заповнені рогом, що розпався, та залишками підстилки, гною, землі.

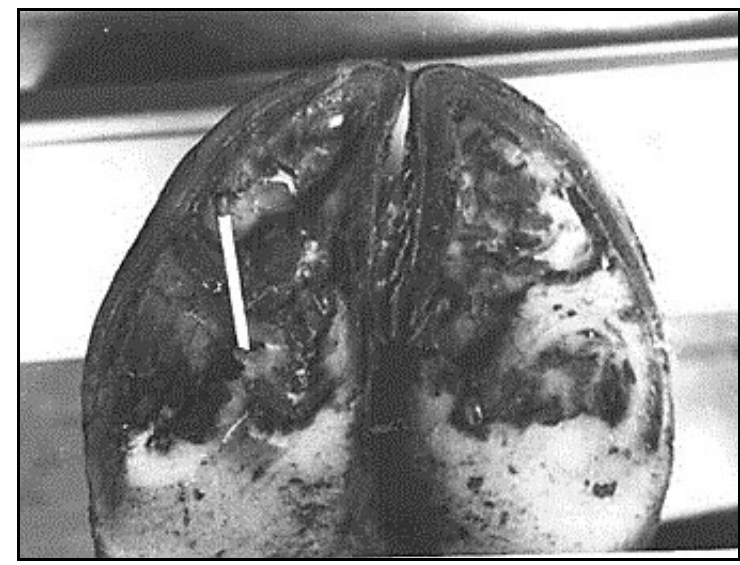

Рис. 5. Утворення дефектів і каналів у товщі підошви копитець

3 часом досить товсті шари підошви відпадають і на їньому місці утворюються значні заглиблення. При цьому зазвичай не пошкоджуються м'які тканини основи шкіри копитця й не розвивається мікозний пододерматит.

Процес гниття підошви часто починається по білій лініі, а потім поступово переходить на стінку копитця, по краях якої можна побачити листочки у вигляді розволокнених ниток. При цьому активніше руйнується трубчастий ріг, що підтверджено лабораторним мікологічним дослідженням - при культивуванні ріст мікроскопічних грибів починається 3 порожнини рогових трубочок з утворенням невеликих колоній гриба у формі грудок вати. Стінка копитця втрачає свій природний блиск, що вказує на руйнування глазурі.
В окремих випадках унгуломікоз починається із зачіпної частини копитця, де $\epsilon$ найтовстіший шар рогової субстанції. Процес зазвичай має хронічний перебіг. Сліди поширення мікозного процесу та глибина ураження чітко відслідковуються на сагітальних розпилах копитець. У цих місцях присутні ознаки ламініту та пододерматиту (рис. 6).

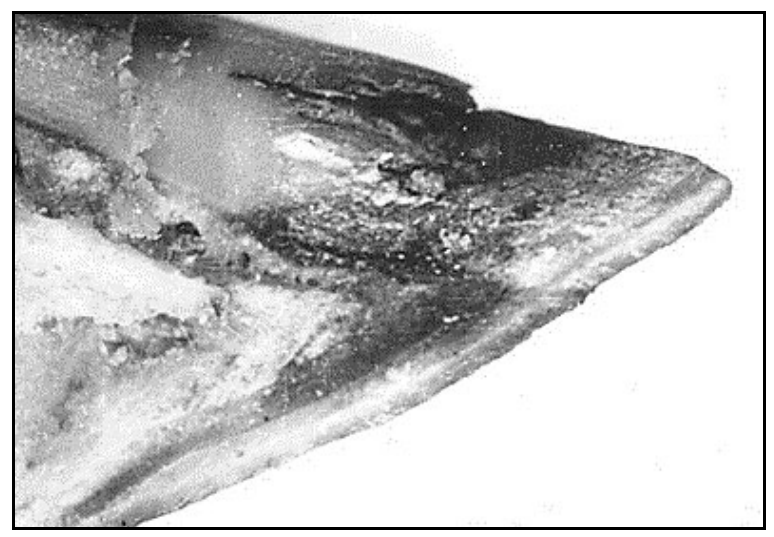

Рис. 6. Сагітальний переріз копитця. Мікотичне ураження зачіпної частини з відшаруванням копитцевого рога

Природно, що руйнування стінки чи підошви копитця (розрихлення, тріщини) зменшує їх механічну міцність. На місці травм розвиваються спочатку асептичні, а потім гнійно-некротичні процеси різного характеру.

Хронічний перебіг унгуломікозу зумовлює деформацію копитця, що призводить до порушення статично-динамічної функції кінцівки, особливо дистальної іiі частини.

Насамперед внаслідок розпаду рогу підошви зменшується площа іiі контакту з поверхнею підлоги, дорожнього покриття чи землі, а це призводить до нерівномірного розподілу статичного тиску (рис. 7). Окремі частини підошви весь час перевантажуються; при цьому виникає больове відчуття, особливо в зоні прикріплення сухожилля глибокого згинача пальця. Спочатку з'являються намулини 3 крововиливами в основу шкіри підошви, внаслідок чого розвивається асептичний пододерматит.

Разом $з$ тим локальні гіпертрофічні процеси, які відбуваються в зоні посиленого навантаження на основу шкіри підошви, зумовлюють дифузні чи вогнищеві розростання рогу, що своєю чергою ще більше ускладнює розподіл статичних сил тиску. Якщо ж причинний фактор не усувається й довго діє, то патологічний процес ускладнюється й на підошовному краю копитцевої кістки утворюються остеофіти та екзостози (рис. 8), які викликають ще більше больове відчуття, особливо під час руху тварини, що призводить до кульгання. При стоянні ж, щоб полегшити біль, тварина часто приймає вимушену позу, внаслідок чого змінюється постава кінцівок, що своєю чергою зумовлює деформацію копитець та дисфункцію зв'язкового апарату. 


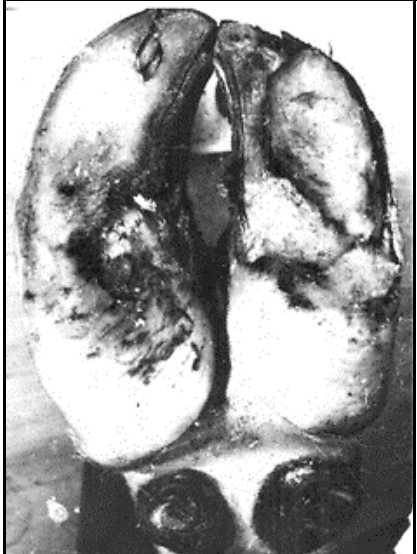

Рис. 7. Деформація підошви, що зумовлює порушення розподілу статичного навантаження

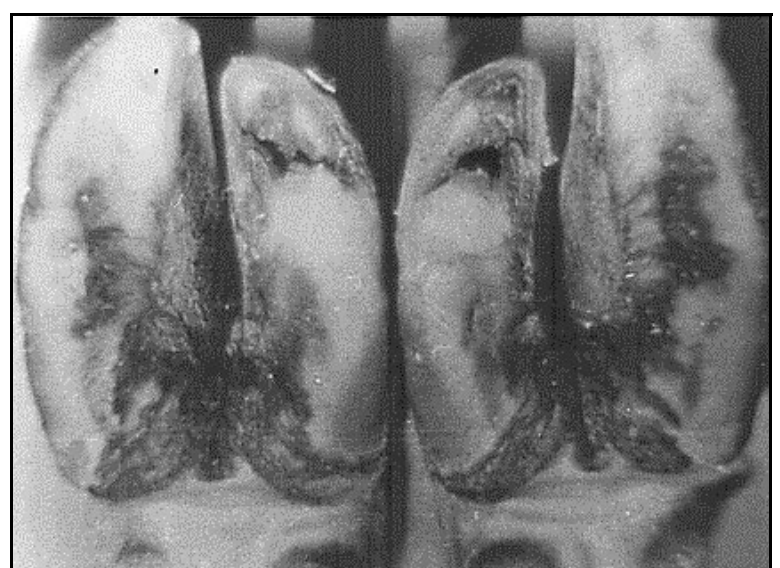

A

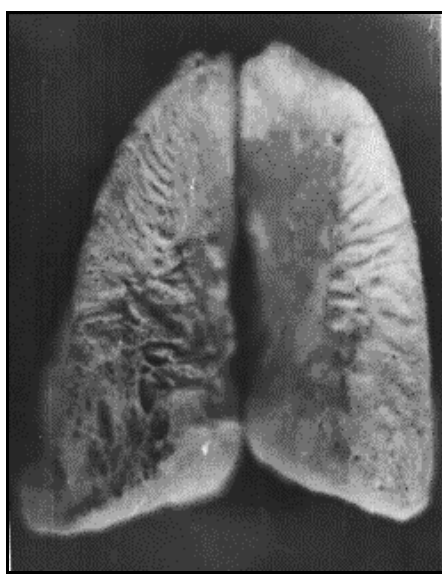

Б

Рис. 8. Симетричні ураження підошви (А). Остеофіти на копитцевих кістках в ділянках посиленого навантаження (Б)

При мікроскопії зразків із зіскребів копитцевого рога наявні численні рогові клітини, позбавлені органоїдів, фрагменти рогових трубочок з відшарованими роговими клітинами, окремі спори й фрагменти септованого міцелію.

Культуральним методом (посів зіскребів рога на поживні середовища Чапека і Сабуро) виявлено, що на п'яту-шосту добу з'являються невеличкі сіро-білі кулясті грудочки майже із симетричними локалізаціями, які з часом формуються у більшу колонію (рис. 9). Зазвичай ріст грибів розпочинається 3 порожнин рогових трубочок, з яких збудована підошва. 3 часом колонії гриба збільшуються і зливаються. В рідких поживних середовищах рогова пластинка проростає наскрізь; в таких випадках з обох сторін колонії формуються симетрично.

Мікроскопічний аналіз показав, що у багатьох випадках міцелій тонкий, довгий, септований (рис. 10) Найчастіше знаходимо гриби із родів тріхофітон, кандида і пліснявих.

Дослідженнями (Kulynych, 2012) встановлено, що у переважній більшості випадків гриби виявляли в асоційованих фармах, зокрема виділено: 3 роду Aspergillus - A. flavus, A. fumigatus; з роду Candida C. albicans; 3 роду Cladosporium $-C$. hordei; 3 роду Mucor - M. species; 3 роду Penicillium - P. urticae, P. expansum, P. chrisogenum; 3 роду Trichoderma T. viridae, T. koningii; 3 роду Acremoniella - A. atra; 3 роду Fusarium - F. sporotrichiella.

Дослідження (Izdepskyi et al., 2012) показали, що найпоширенішими грибами, які виділили зі зразків копитного рогу, є Scop. brevicaulis, Alt. alternata, Asp. flavus, Asp. fumigatus та Penicillium - іх частка складала майже 73 \%. Автори зауважили, що всі гриби переважно виділяються із поверхневих шарів, і лише Scopulariopsis brevicaulis в 1,5 раза частіше реєструвався в глибоких ураженнях, що дало підставу вважати цей вид основною причиною розвитку глибоких деструктивних процесів.

Подальші дослідження (Khomyn et al., 2020) підтвердили причетність мікроскопічних грибів (A. flavus, C. hordei, T. viridae, T. koningii) до руйнування копит- цевого рогу та ускладнення перебігу гнійного пододерматиту.

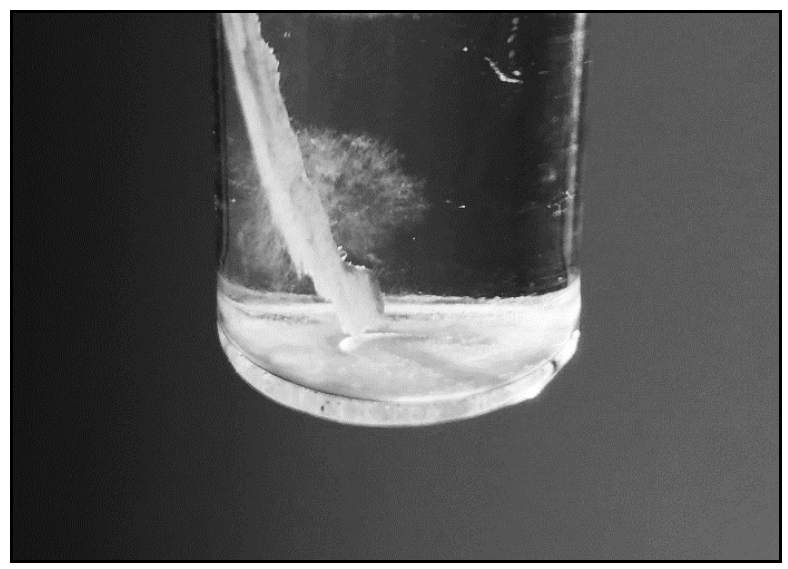

Рис. 9. Формування колонії мікроскопічного гриба на зіскребі копитцевого рога

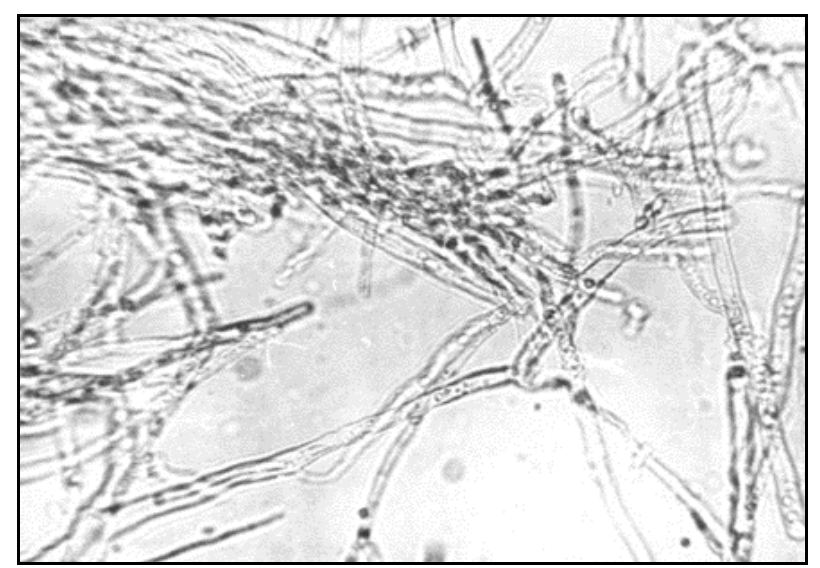

Рис. 10. Міцелій, вирощений на твердому

живильному середовищі. Окремі гіфи септовані

Варто зауважити, що більшість мікроскопічних грибів, які $\epsilon$ збудниками мікозів, аероби; частіше уражають органи і тканини, що контактують із зовнішнім середовищем (Harchenko et al., 1982). 
Мікроскопічні гриби широко поширені в природі. Вони є у грунті, воді, рослинах, а також заселяють організми тварин і людини. Найбільша кількість мікроорганізмів, зокрема грибів, актиноміцетів і бактерій, перебувають на глибині 5-15 см. Мікрофлора водойм особливо насичена у поверхневих шарах прибережної зони й прямо залежить від ступеня їхнього забруднення. Кількість мікроорганізмів у повітрі приміщень значно більша, ніж у повітрі відкритих місць, особливо за недостатньої їх вентиляції й недотримання санітарних вимог; тут часто виявляються актиноміцети, плісняві й дріжджові гриби та ін. На поверхневих частинах рослин завжди присутні дріжджі і плісняві гриби. Щодо силосованого корму, то його якість може зберігатися до трьох років, а потім починають розмножуватися дріжджі, плісені, маслянокислі й гнилісні бактерії і силос псується. Як відомо, при доступі повітря запліснення силосу пришвидшується (Emel'janenko et al., 1982).

Товста кишка тварин найбільш багата мікроорганізмами. Тут містяться, окрім бактерій, актиноміцети, дріжджі, плісені, а також велика кількість гнилісних і деяких патогенних анаеробів. Оптимальні умови для мікробів є в гною, де за оптимальної температури та достатньої аерації, окрім бактерій, які розкладають органічні речовини, інтенсивно розмножуються актиноміцети та плісняві гриби, особливо Aspergillus, Penicillium, Monillia, Cladosporium (Emel'janenko et al., 1982).

Очевидно, де тварини утримуються в антисанітарних умовах, при несвоєчасному прибиранні гною, залишків корму, зокрема силосу, занесенні транспортними засобами грунту тощо, там будуть інтенсивно накопичуватися різного роду бактерії, такі як Staphylococcus aureus, Staphylococcus epidermidis, Escherichia coli, Diplococcus septicus й мікроскопічні гриби (Khomyn et al., 2020).

Як відомо, загальноприйнятої класифікації грибів на даний час не існує. За основу класифікації найчастіше беруть спосіб їх розмноження.

Щодо класифікації мікозів, то у вітчизняній медичній мікробіології і лабораторній діагностиці виділяють шість груп даного захворювання: 1) поверхневі мікози (кератомікози) - ураження поверхневих шарів шкіри та волосся; 2) епідермофітії (емідермомікози, дерматомікози) - ураження епідермісу, дерми, волосся; 3) підшкірні (субкутанні) мікози - ураження дерми, підшкірної клітковини та м'язів; 4) міцетома - хронічний гнійнозапальний процес підшкірної клітковини і суміжних тканин; 5) глибокі (системні) мікози - ураження внутрішніх органів і тканин; 6) опортуністичні мікози аспергільоз, зигомікоз, пеніциліоз, фузаріоз, кандидоз, пневмоцистоз (Minukhin et al., 2016).

Останніми роками у вітчизняній дерматології найчастіше використовують класифікацію Н. Д. Шеклакова (Kuts \& Hortynska, 2019). Відповідно до неї виділяють чотири групи мікозів і групу псевдомікозів: 1) кератомікози; 2) дерматомікози; 3) кандидози; 4) глибокі (вісцеральні, системні) мікози. Псевдомікози теж поділяють на поверхневі й глибокі. Зокрема, до глибоких належить актиномікоз.
Прийнятна також класифікація грибкових захворювань шкіри залежно від етіології: 1) мікози, зумовлені дерматофітами; 2) мікози, зумовлені дріжджоподібними грибами; 3) мікози, зумовлені пліснявими грибами.

У ветеринарній медицині виділяють три групи мікозів тварин, які викликаються патогенними грибами (Harchenko et al., 1982): 1) поверхневі мікози шкіри та iii похідних; збудники - гриби із групи Trichophiton, Microsporum i Achorion; 2) глибокі мікози шкіри, які характеризуються утворенням вузлів у шкірі 3 подальшим утворенням вузлів та виразок за ходом лімфатичних судин; збудник - гриб із роду Histoplasma / Sin. Criptococcus farciminosus Riv.; 3) вісцеральні мікози 3 локалізацією процесу в органах дихання; можуть уражати інші органи і тканини; збудники - паразитні і сапрофітні гриби.

На думку С. В. Петровича (Petrovich, 1989), всі мікози тварин варто умовно розділяти на дві великі групи: 1) поверхневі мікози (дерматофітози) - трихофітія, мікроспорія, фавус; 2) глибокі (вісцеральні) мікози, за яких уражаються внутрішні органи і тканини, - епізоотичний лімфангіт, споротріхоз, бластомікоз північноамериканський, кріптококоз, гістоплазмо3, кокцидіоідомікоз, риноспоридіоз, аспергільоз, мукоромікоз, пеніцилліомікоз, міцетоми. Разом з тим, автор зауважує, що в деяких випадках за поверхневих мікозів (трихофітія) можуть уражатися внутрішні органи і глибше лежачі тканини, а за вісцеральних мікозів (кандидоз) - лише шкіра.

Необхідними компонентами для живлення мікроскопічних грибів $\epsilon$ вуглець, кисень, водень, азот, сірка, фосфор, калій, магній та ін. Джерелом вуглецю $є$ різні мінеральні й органічні сполуки, пептони, амінокислоти й вуглеводи. Різні мікроелементи (цинк, марганець, мідь, молібден та ін.) стимулюють розвиток грибів, а разом з вітамінами позитивно впливають не тільки на ріст і розвиток, а й на інтенсивність спороутворення.

Якщо порівняти склад необхідних компонентів для формування копитцевого рогу та живлення мікроскопічних грибів, то дійдемо таких висновків: 1) наявність необхідних мінеральних й органічних сполук й на копитцевому розі створює сприятливі умови для розвитку мікроскопічних грибів, зокрема кератоміцетів (Khomyn et al., 2017); 2) руйнування копитцевого рогу та його деформації сприяють поширенню та накопиченню грибкової флори, яка проявляє свою патогенну дію (Izdepskyi et al., 2012); 3) за неповноцінної годівлі, особливо при остеодистрофії, та дії мікроскопічних грибів (унгуломікоз) прискорюється процес руйнування копитцевого рогу.

Як показали наші дослідження (Krupnyk et al., 2013), у корів виявлено порушення обміну речовин, яке характеризується низькими показниками в крові загального білка, глюкози, каротину, загального кальцію, неорганічного фосфору, йоду, кобальту, міді, марганцю й лужного резерву при верхніх межах норми показників натрію, калію та лужної фосфатази. Саме через цей аліментарний фактор широко задіяні механізми остеодистрофії та зниження механічної стійкості копицевого рогу. 


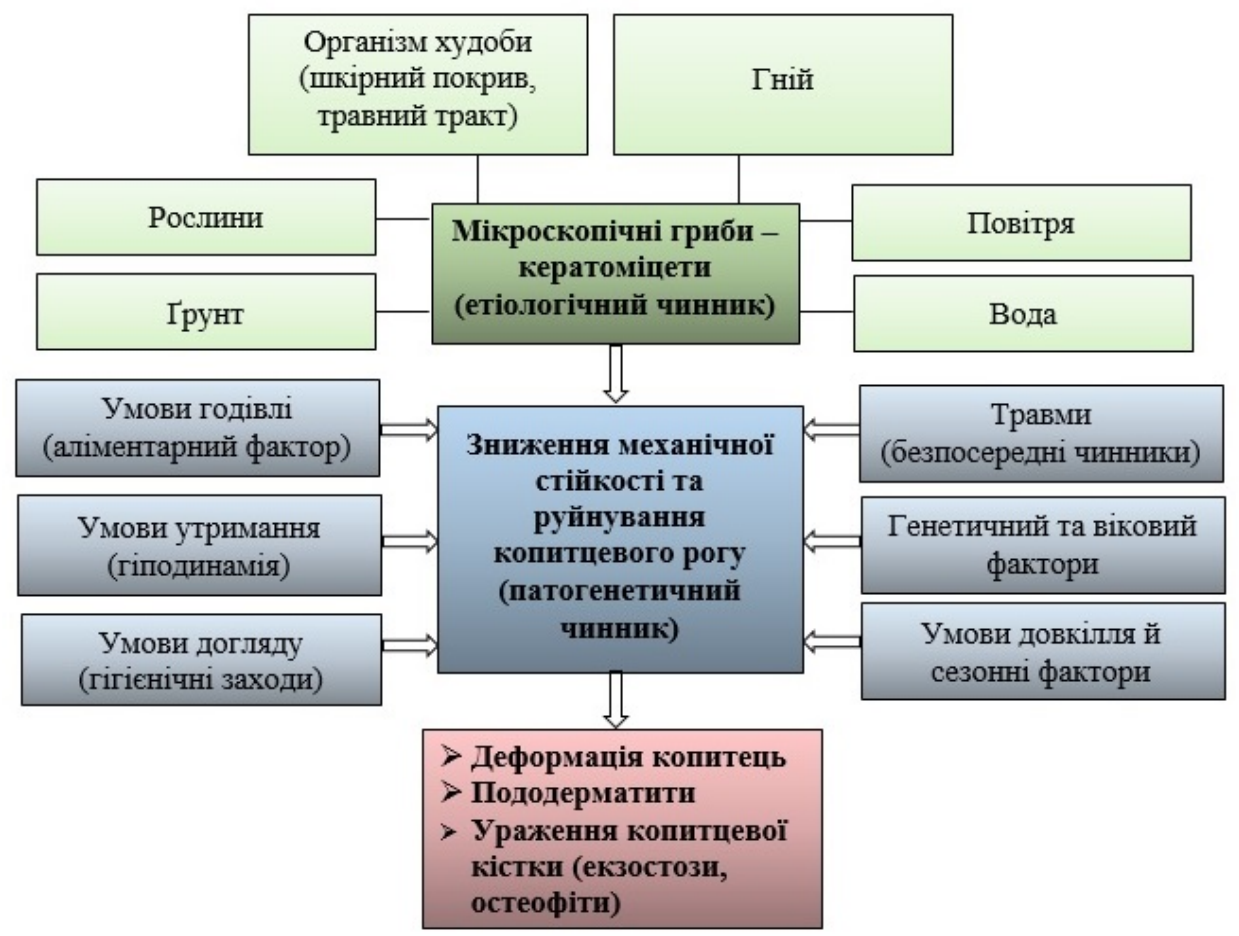

Рис. 11. Схема етіопатогенезу унгуломікозу

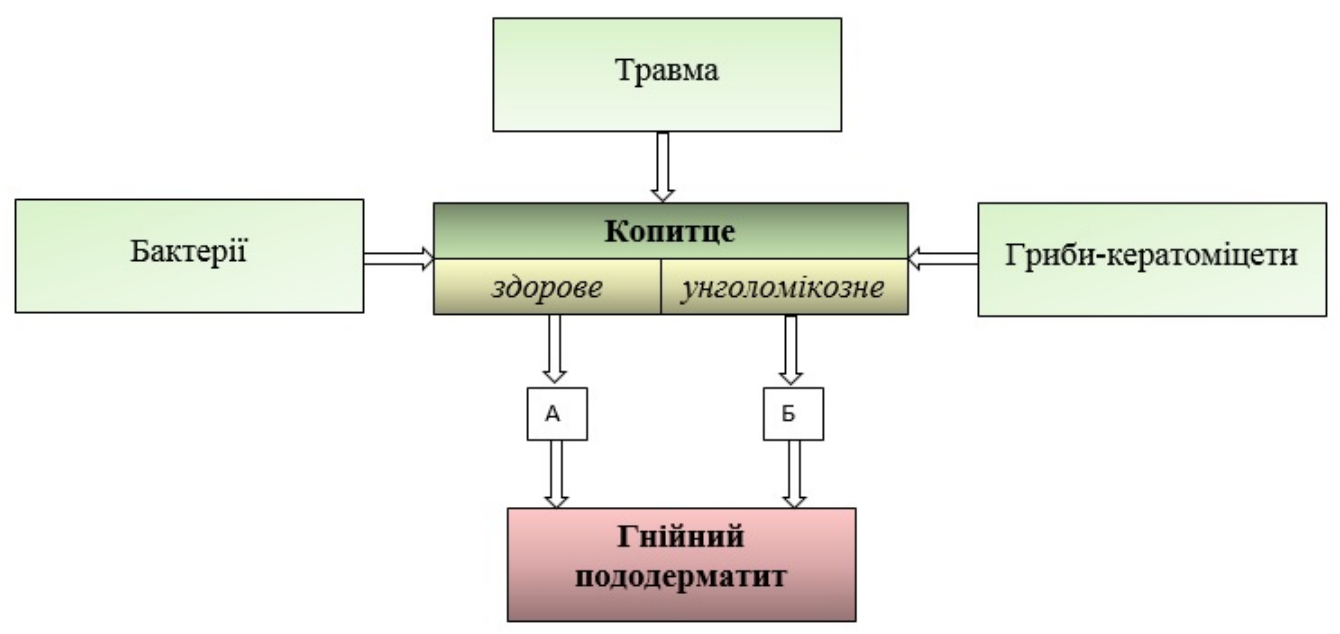

Рис. 12. Схема етіопатогенезу гнійного пододерматиту, ускладненого кератоміцетами (А - додатковий фактор; Б - сприяючий фактор).

Встановлено (Borisevich, 1996), що у зв’язку з неповноцінною годівлею, зокрема за остеодистрофії, спостерігаються масові захворювання копитець, оскільки при цьому погіршується опорна функція кінцівок, виникають відхилення в їх поставі; формуються копитця 3 крихким і ламким рогом. До цього спричинюється нестача в організмі незамінних сірковмісних амінокислот, вітамінів, макро - та мікроелементів (сірки, кальцію, фосфору, цинку, міді, кобальту). Невідповідні умови утримання (короткі й надмірно похилі (понад $6^{\circ}$ ) стійла, підвищена вологість, гіподинамія) безпосередньо спричиняють травмування м'якушів підошви, виникнення намулень, пододерматитів, деформацій копитець.
Велике значення мають гігієнічні заходи й правильна розчистка копитець, що безпосередньо сприяє усуненню основного етіологічного чинника та служить допоміжним заходом у лікуванні унгуломікозу.

Отже, в етіопатогенезі унгуломікозу задіяні такі складові: а) мікроскопічні гриби-кератоміцети; б) травмований чи зі зниженою механічною стійкістю копитцевий ріг; в) сприятливі умови для розмноження кератоміцетів та супутньої симбіотичної мікрофлори (рис. 11).Таким чином, етіологічна роль мікроскопічних грибів-кератоміцетів за унгуломікозу є основною, тимчасом як за пододерматиту травматичного походження може бути допоміжною - як додатковий чи сприяючий фактор (рис. 12). 


\section{Висновки}

1. Унгуломікоз (від лат. ungula - копито, гр. mykes - гриб) - захворювання копитець, які спричинюються мікроскопічним грибами, що мають кератолітичні властивості.

2. Захворювання $є$ самостійною нозологічною одиницею, яку доцільно включати в комплекс диспансеризаційних заходів.

3. Унгуломікоз худоби призводить до виникнення деформацій копитець, асептичного та гнійного пододерматитів, ураження копитцевої кістки (остеофіти, екзостози).

4. За гнійного пододерматиту травматичного походження унгуломікоз є одним із сприяючих факторів розвитку та перебігу захворювання.

5. Мікроскопічні гриби за неповноцінної годівлі, особливо при остеодистрофії, прискорюють процес руйнування копитцевого рогу.

Перспектива подальших досліджень. Дослідження будуть спрямовані на розробку ефективних методів лікування та заходів профілактики унгуломікозу.

Відомості про конфлікт інтересів. Автори стверджують про відсутність конфлікту інтересів щодо їх вкладу та результатів досліджень.

\section{References}

Borisevich, V. B. (1996). Bolezni kopytec i kopyt. K. (in Russian).

Emel'janenko, P. A., Dunaev, G. V., \& Kudlaj, D. G. (1982). Veterinarnaja mikrobiologija. M.: Kolos (in Russian).

Harchenko, S. N., Litvin, V. P., \& Tarabara, I. M. (1982). Spravochnik po mikozam i mikotoksikozam sel'skohozjajstvennih zhivotnih. Kiev: Urozhaj (in Russian).

Izdepskyi, V. I., Kulynych, S. M., \& Kabluchko, A. P. (2012). Deiaki biokhimichni pokaznyky vplyvu mikroskopichnykh hrybiv na tkanyny kopytnoho rohu u tvaryn. Nauk. visnyk vet. medytsyny: Zb. nauk. prats. Bila Tse-rkva, 9(92), 66-70 (in Ukrainian).
Khomyn, N., Mysak, A., Tsisinska, S., \& Pritsak, V. (2017). The quality of the hoof horns of cattle and the influence of certain etiological factors. Scientific Messenger of LNU of Veterinary Medicine and Biotechnologies. Series: Veterinary Sciences, 19(82), 175-179. URL: https://nvlvet.com.ua/index.php/ journal/article/view/1360.

Khomyn, N., Mysak, A., Tsisinska, S., Pritsak, V., Nazaruk, N., \& Lenjo, Y. (2020). Features of cows treatment with purulent pododermatitis complicated by keratomycetes. Scientific Messenger of LNU of Veterinary Medicine and Biotechnologies. Series: Veterinary Sciences, 22(99), 94-100. doi: 10.32718/nvlvet9915.

Kisera, Y., Storchak, Y., \& Bozsik, L. (2017). Special composition of circular microflora and its stability to antibacterial preparations in the conditions of PAF «Brezhnitsya» of the Zhedachivsky district of Lviv region. Scientific Messenger of LNU of Veterinary Medicine and Biotechnologies. Series: Veterinary Sciences, 19(78), 172-176. doi: 10.15421/nvlvet7835.

Krupnyk, Ya. H., Mysak, A. R., Tsisinska, S. V., Demydiuk, S. K. (2013). Osteodystrofiia velykoi rohatoi khudoby: osnovni faktory, patohenetychni mekhanizmy, profilaktychni zakhody. Veterynarna medytsyna Ukrainy, 7(209), 15-21 (in Ukrainian).

Kulynych, S. M. (2012). Urazhennia kopytets u koriv, sprychyneni keratomitsetamy: avtoref. dys. d-ra vet. nauk: 16.00.05. Kyiv (in Ukrainian).

Kuts, L. V., \& Hortynska, O. M. (2019). Mikozy: navchalnyi posibnyk. Sumy: Sumskyi derzhavnyi universytet, 83 (in Ukrainian).

Malishevs'kij, E. A., Zavirjuha, V. I., Gamota, A. A., Misak, A. R., \& Samsonjuk, V. G. (1991). Ungulomikoz u krup-nogo rogatogo skota. Problemy hirurgicheskoj patologii sel'skohozjajstvennyh zhivotnyh. Tez. dokl. Vsesojuzn. Nauch. konf. Belaja Cerkov', 88-89 (in Russian).

Minukhin, V. V., Zamazii, T. M., \& Kovalenko, N. I. (2016). Patohenni hryby: metodychni vkazivky. Kharkiv: KhNMU (in Ukrainian).

Petrovich, S. V. (1989). Mikozy zhivotnyh. M.: Rosagropromizdat (in Russian). 